\title{
Neotectonics as a structural control of the boundaries of the Pantanal Matogrossense Sub-Regions
}

\section{CAMILA L. MIOTO ${ }^{1}$, GUSTAVO AMORIM ${ }^{2}$, ROMULO MACHADO ${ }^{3}$, FABRÍCIO B. DALMAS ${ }^{4}$, ANA PAULA G. OLIVEIRA ${ }^{5}$, ANTONIO R. SAAD ${ }^{6}$, MARCO ANTONIO DIODATO ${ }^{7}$ and ANTONIO C. PARANHOS FILHO ${ }^{2}$}

\author{
${ }^{1}$ Laboratório de Geoprocessamento, Instituto de Ciências Agrárias e Tecnológicas, Universidade Federal de Mato Grosso, \\ Campus Universitário de Rondonópolis, MT 270, Km 06, Sagrada Família, 78735-901 Rondonópolis, MT, Brazil \\ ${ }^{2}$ Laboratório de Geoprocessamento para Aplicações Ambientais, Faculdade de Engenharias, Arquitetura e Urbanismo e \\ Geografia, Universidade Federal de Mato Grosso do Sul, Cidade Universitária, s/n, 79070-900 Campo Grande, MS, Brazil \\ ${ }^{3}$ Universidade de São Paulo, Instituto de Geociências, Rua do Lago, 562, Butantã, 05508-080 São Paulo, SP, Brazil \\ ${ }^{4}$ Programa de Mestrado em Análise Geoambiental da Universidade Guarulhos, Universidade \\ UNG, Praça Tereza Cristina, Centro, 239, 07023-070 Guarulhos, SP, Brazil \\ ${ }^{5}$ Programa de Pós-Graduação em Meio Ambiente e Desenvolvimento Regional, Universidade Uniderp \\ - Anhanguera, Rua Alexandre Herculano, 1400, 79037-280 Campo Grande, MS, Brazil \\ ${ }^{6}$ Geólogo autônomo, Rua Professor Lúcio Martins Rodrigues, 6, Morumbi, 05621-025 São Paulo, SP, Brazil \\ ${ }^{7}$ Centro de Ciências Agrárias, Universidade Federal Rural do Semiárido, Avenida \\ Francisco Mota, 572, Costa e Silva, 59625-900 Mossoró, RN, Brazil
}

Manuscript received on September 5, 2017; accepted for publication on May 11, 2018

\begin{abstract}
How to cite: MIOTO CL, AMORIM G, MACHADO R, DALMAS FB, OLIVEIRA APG, SAAD AR, DIODATO MA AND PARANHOS FILHO AC. 2019. Neotectonics as a structural control of the boundaries of the Pantanal Matogrossense Sub-Regions. An Acad Bras Cienc 91: e20170697. DOI 10.1590/0001-3765201920170697.
\end{abstract}

\begin{abstract}
Characterized by fluvio-alluvial sedimentation processes, the heterogeneity in the Pantanal Basin allows its division in several sub-regions, which present natural characteristics of their own. It is possible to find in the literature different proposals to subdivide the Pantanal plain, which vary in total area and number of subregions. Each author uses specific criteria - mainly vegetation, soil and humidity - in his delimitation, but does not consider the tectonic aspects of the basin. In this sense, we intend to analyze three Pantanal delimitations from the literature and to relate them to the neotectonic context of the Pantanal plain by comparing the boundaries proposed in the delimitations to structural lineaments present in the basin. As a result, we observe that the comparison of the Pantanal boundaries with the lineaments shows a high compatibility between them, suggesting the influence of these structures in the development of the sub-regions.
\end{abstract}

Key words: Remote sensing, structural lineaments, geoecological context, Paraguay River Basin.

\section{INTRODUCTION}

Located in the Upper Paraguay Hydrographic Basin, Pantanal is a unique and peculiar region. One of its peculiarities is the heterogeneity, which

Correspondence to: Camila Leonardo Mioto

E-mail: ea.mioto@gmail.com

ORCid: https://orcid.org/0000-0002-6951-9527 allows the division of Pantanal in several subregions, well known as Pantanais, which present characteristics of their own, such as vegetation, sedimentation and flood dynamics (Mioto et al. 2012, Assine et al. 2016).

Besides these characteristics, Pantanal is a tectonically active sedimentary region, with 
evidences of present and recent tectonic activity (Branner 1912, Ab'Saber 1988, 2006, Ussami et al. 1999, Assine 2010, Assine and Soares 2004, Hasui 1990, 2010, Assumpção and Suárez 1988, Assumpção et al. 2009a, b, Facincani et al. 2011, Zani and Assine 2011, Assine et al. 2016, Paranhos Filho et al. 2013, 2017). Assine (2010) indicates the presence of active faults possibly related to the Transbrasiliano Lineament.

Structural lineaments are essential elements to help understand such context. Lineaments can be understood as mappable linear features of a surface whose parts are aligned in a rectilinear or curvilinear relationship and that differ from the patterns of adjacent features and presumably reflect a subsurface phenomenon of the terrain (O'Leary et al. 1976). According to Andrades Filho and Fonseca (2009), these features can represent faults or crustal weaknesses of the terrain.

In this aspect, structural lineament systems have already been identified in the Pantanal plain that indicate the presence of structures associated with an active tectonics. The fact that the basin is filled with recent sediments that can be easily remobilized by fluvial systems ends up masking the structural system (Paranhos Filho et al. 2013). Therefore, it is presumed that there must be an active structural control that keeps the lineaments visible and the drainage patterns under an intense depositional regime.

Several papers deal with the influence of the structural lineaments on the Pantanal drainage (Assine and Soares 2004, Kuerten and Assine 2011, Paranhos Filho et al. 2017). Assine and Soares (2004) and Kuerten and Assine (2011) present some points where the Paraguay River is directly conditioned by tectonics. In turn, Paranhos Filho et al. (2017) analyze the hydrographic system that composes the Pantanal plain and observe that tectonics plays a preponderant role in the structural conditioning of the main rivers of the plain. The majority of these rivers follow an E-W trend, whereas at the borders of the plain the preferential direction is N-S, which is that of the Paraguay River. Such characteristic has influence on the biodiversity in the region, once water is the main agent that regulates all the operations in Pantanal.

Besides these structures, the occurrence of earthquakes in Pantanal also evidences present tectonic activities. Thirty-nine earthquakes were recorded between 1876 and 2015, according to the Boletim Sísmico Brasileiro (Brazilian Seismic Bulletin), version 2014.6 (USP 2014) and the updated data of the Institute of Astronomy, Geophysics and Atmospheric Sciences of São Paulo University (USP 2016) (Fig. 1).

The distribution of events follows a relatively heterogeneous pattern, but there is a striking constancy in their amount and location. From 1990 to 2010 , twenty events were recorded in the Taquari River mega-fan (Almeida et al. 2015). From this fact it can be assumed that there are structures that play an important role in this scenario (Soares et al. 1998, Assine and Soares 2004, Facincani et al. 2011).

The literature presents several divisions in sub-regions for the Pantanal. In this context, we aim to analyze how neotectonics exerts structural control on the limits of the Pantanal sub-regions using three of the main delimitation models presently available: Adámoli (1982), Silva and Abdon (1998), and Mioto et al. (2012).

\section{GEOLOGICAL CONTEXT}

The Pantanal Basin belongs to the Upper Paraguay Hydrographic Basin (BAP), occupying approximately $140,000 \mathrm{~km}^{2}$ of BAP, which totalizes $370,000 \mathrm{~km}^{2}$ (Fig. 2). The Paraguay River flows from north to south, mostly in the Brazilian territory, being the main collector of all the water that enters the plain. With a very unstable bed, during the rainy seasons it rises 2 to $3 \mathrm{~m}$ above the mean level, isolating many isles. Its declivity 


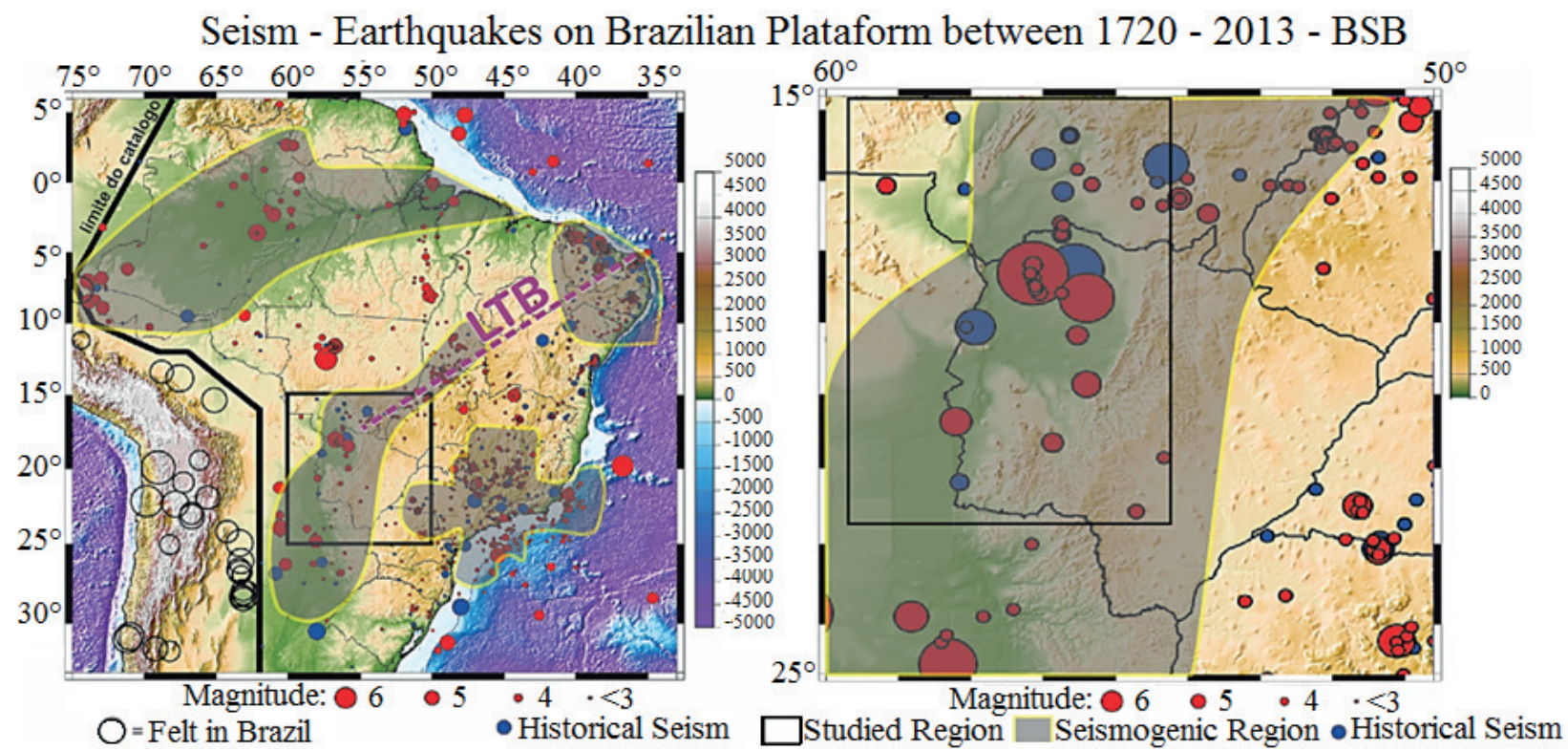

Figure 1 - Events recorded in the Brazilian Seismic Bulletin (BSB - V2014.6).

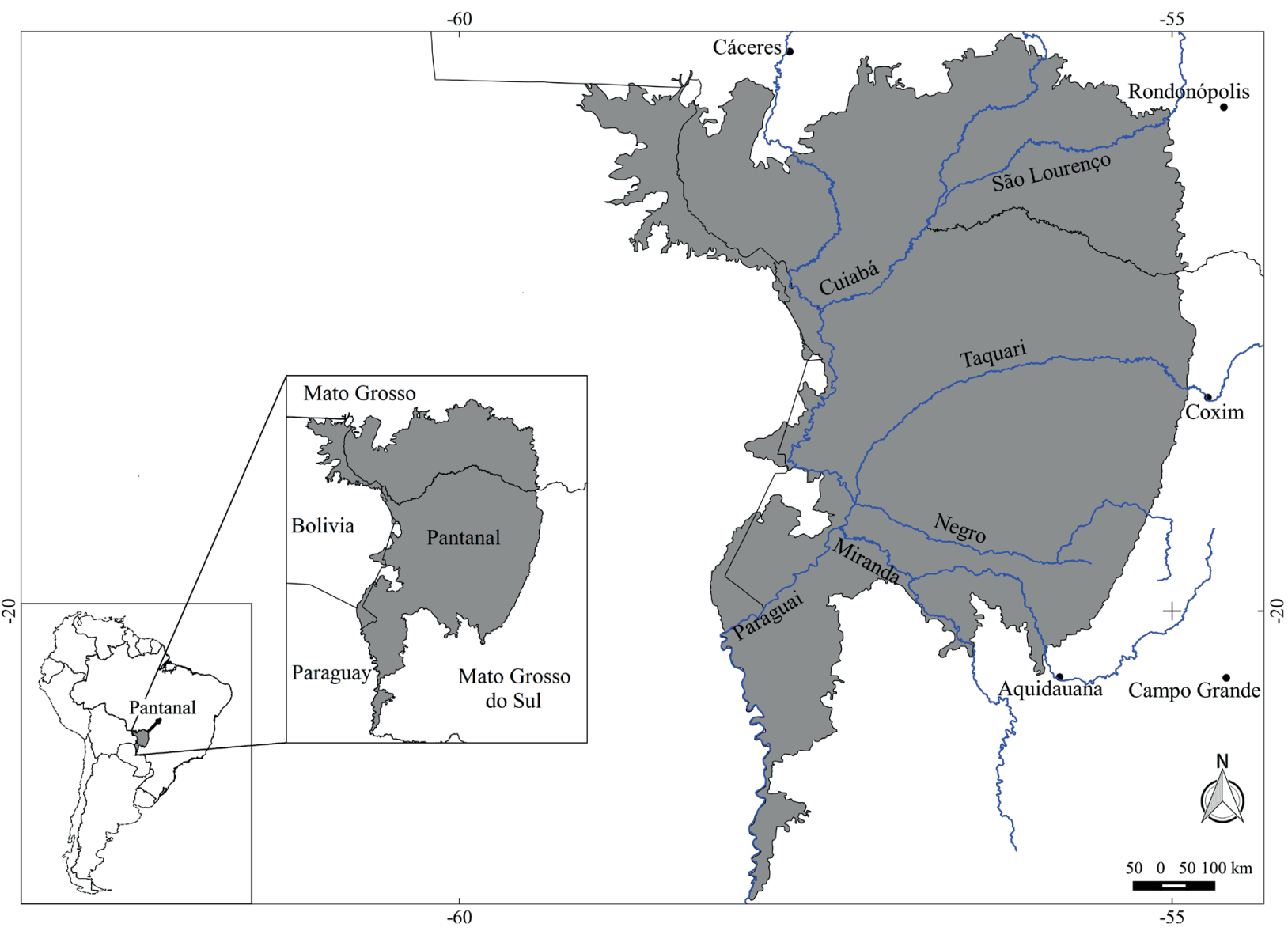

Figure 2 - The location of Pantanal. The Pantanal boundary presented in grey is proposed by Mioto et al. (2012), who consider that Pantanal extends to Bolivia and Paraguay. 
is very low, varying from some millimeters to centimeters per kilometer (Almeida 1945).

Ussami et al. (1999) showed that the Pantanal region is a shallow depression resulting from sub-Andean foreland flexural bulge that reached the Neoproterozoic Paraguay fold-thrust belt. According to these authors, the subsidence mechanism can be considered as a modern analogue of an intracratonic basin. Therefore, progressive basin subsidence would lead to the accumulation of thick sediment pile similar to cratonic basins.

According to Assumpção (1998), the origin of Pantanal is related to the density contrast between the South-American (continental) and Nazca (oceanic) lithospheric plates, generating subduction zones and uplift of the Andean Cordillera. This movement has caused an overburden on the continental crust with the deposition of a foreland system to the east of the cordillera, which includes the eastern SubAndean Zones - the Chaco and Pantanal plains, respectively located in the foredeep and backbulge. The backbulge beneath the Pantanal is an ample and thin accumulation of sediments on both the forebulge and the craton. In the long term, the migration of such foreland basin system produces a stratigraphic-structural profile in which successive locations of each depozone can be determined throughout the growth of an adjacent fold-thrust belt (Horton and DeCelles 1997).

Although several pioneer studies have suggested that at least part of the subsidence of the Grande Chaco Sedimentary Basin was controlled by faults, with some of them well known in Brazilian and Paraguayan territories, such as the Serra da Bodoquena and Lago of Ipacaraí faults, respectively (Eckel et al. 1959, Putzer 1962, Almeida 1965), Freitas (1951) was probably the first researcher to refer to the Pantanal Basin as the only large quaternary tectonic basin in the Brazilian territory.

Almeida (1965, 1967) characterizes two areas of sedimentation on the South American
Platform during the Quaternary: the Amazon and the Pantanal basins, and also identifies NNE-SSW structures that affect the Gran Chaco in Bolivia and Paraguay, and the Paraguay river basin, representing two separated tectonic compartments, limited by the hills along the border between Brazil and Bolivia.

Riccomini and Assumpção (1999) explain that the concept of tectonic stability has long prevailed for most of the South American Platform and that the investigation on Quaternary tectonics in Brazil has only begun in the 1990's.

Assumpção et al. (2013a, b), based on geophysical investigations, showed that the crust in the Pantanal region and some areas of the Chaco basin is thinner $(<30-35 \mathrm{~km})$ than the average crust thickness than that of other regions of the Brazilian platform. They also consider that this is a feature probably inherited from the old pre-Cambrian evolution of the South American continent.

Studies of the structural lineaments conducted by Paranhos Filho et al. (2013) along the Pantanal Basin and its basement, based on CBERS-2B satellite images (Wide Field Imager Sensor - WFI) combined with field informations, show directions concentrated around ENE and WNW in the Pantanal area, and secondarily EW and NW-SE, whereas in its surroundings they are concentrated around NE and N-S. These last two directions are considered older and related to reactivations of basement structures. The youngest E-W directions were developed from the end of the Cenozoic to the Quaternary. Therefore, the Pantanal Basin has active tectonics and its evolution seems to be linked with changes that occurred during the Andean subduction.

Recently, Paranhos Filho et al. (2017), based on the analysis of the drainage pattern in Pantanal and its surroundings, showed the existence of asymmetrical patterns of all the watersheds, which is compatible with the existence of a structural 
conditioning of the main rivers that form the Pantanal.

As mentioned before, Pantanal can be divided in distinct sub-regions. In general, the proposals found in the literature are supported by physiographic criteria and indirectly by pedology, geology, geomorphology and ecology, without considering tectonic aspects, which are important criteria, once Pantanal is a tectonically active basin. Because there is no consensus regarding limits or boundaries, this areal variation hinder the application of normative instruments, as well the allocation of specific financial support to the biome (Silva and Abdon 1998, Mioto et al. 2012).

The studies of Adámoli (1982), Silva and Abdon(1998) and Mioto et al. (2012) arehighlighted here. Adámoli (1982) divides the Pantanal plain in 10 different sub-regions distributed over $139,111 \mathrm{~km}^{2}$. This author takes into consideration phytogeographical aspects associated with ecological characteristics and flood levels and uses data from previous studies, such as 1:250,000 and 1:1,000,000 LANDSAT-MSS images (Silva 1995).

Silva and Abdon (1998) delimits the Pantanal from a mosaic composed of Landsat 5, sensor TM images of different acquisition dates, topographic charts and previous studies, plus aspects related to flooding, relief, soil and vegetation. The results of such study are a major unit (Pantanal) with 11 subregions, totalizing $138,183 \mathrm{~km}^{2}$.

Mioto et al. (2012) used pairs of CBERS2B, WFI, TERRA/AQUA, and MODIS satellite images of the same date to equilibrate differences in phenology and humidity, which were observed in mosaics used in previous classifications. Thus, with this set of images, the authors delimited 18 different sub-regions, totalizing $140,640 \mathrm{~km}^{2}$. They also took into consideration physiographic and hydrological aspects, flooding and vegetation.

It is worth pointing out that none of the three studies took into consideration structural aspects.

\section{METHODOLOGY}

In order to check the effect of neotectonics structural control on the delimitation of the Pantanal boundaries, we analyze three groups of Pantanal sub-divisions, which present similarities among them: Adámoli (1982), Silva and Abdon (1998) and Mioto et al. (2012) (Fig. 3). It is important to point out that the Pantanal limits or boundaries analyzed in this study were obtained by photointerpretation carried out by different research groups in distinct operational contexts. The fact that the three interpretations show similarities among them leads us to think that physical boundaries really exist, being represented by some structure in the terrain.

The structural lineaments used in this study were proposed by Paranhos Filho et al. (2013), obtained by means of the photointerpretation of CBERS-2B, sensor WFI satellite images and the normalized difference vegetation index (NDVI). The authors, observing the set of images, identified three groups of lineament trends: NE, around N-S and E-W (Fig. 4). The results corroborate to the fact that the presence of structures of such magnitude is associated with active tectonics, once the basin is filled with recent sediments that can be easily remobilized by the fluvial systems operating in the basin, thus masking the structural system. In this sense, the authors indicate that there must be some kind of active structural control that keeps the lineaments visible and the drainage under an intense depositional regime.

Thus, structural lineaments were observed in this study that, overlain on each of the Pantanal boundaries, helped visually identify the coincidence between such boundaries and lineaments. The whole data interpretation and the preparation of layouts were performed using the software QGIS version 2.12 - Lyon (QGIS Development Team 2015), which is a freeware GIS application. 

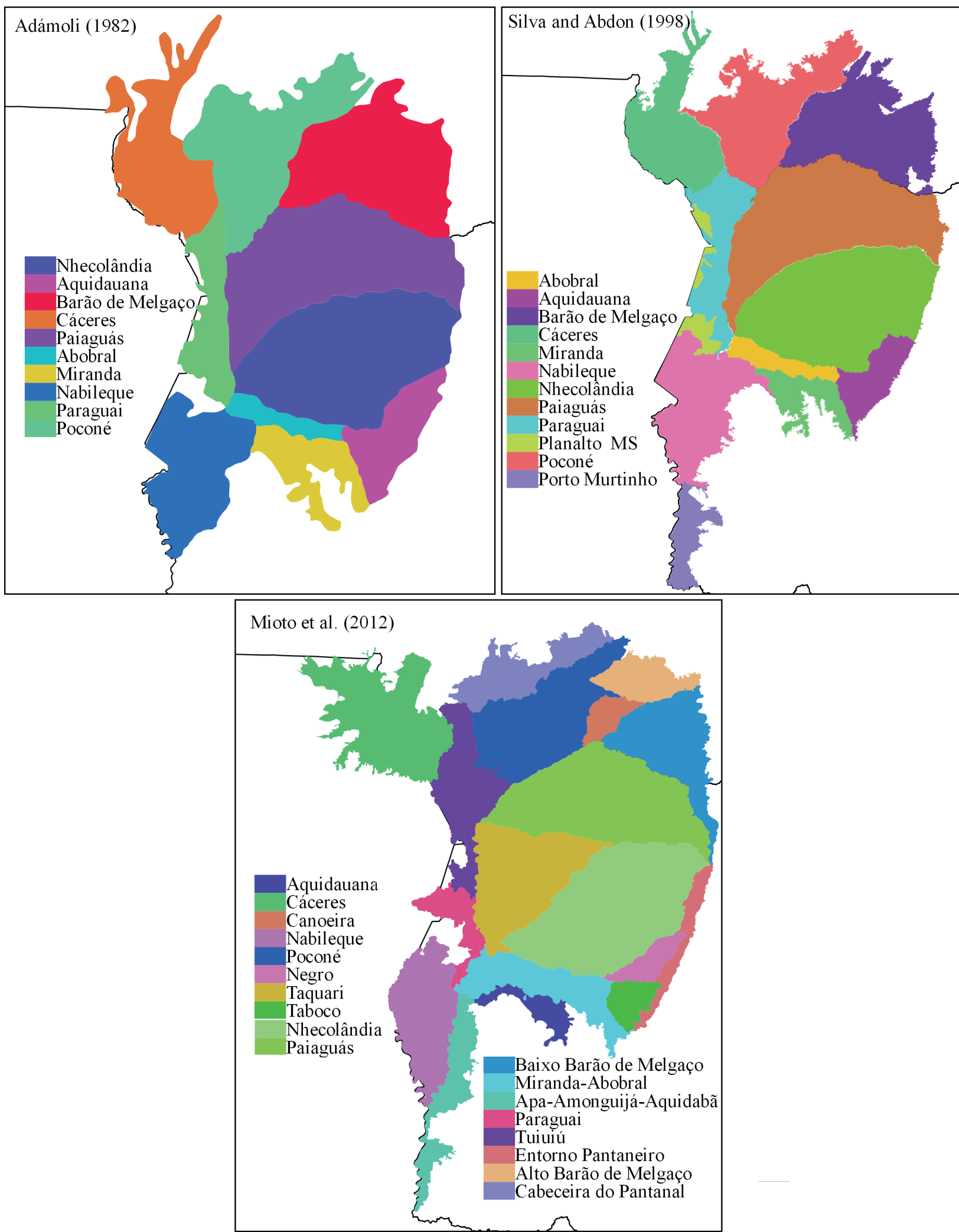

Figure 3 - The boundaries of the Pantanal sub-regions used in this paper. 


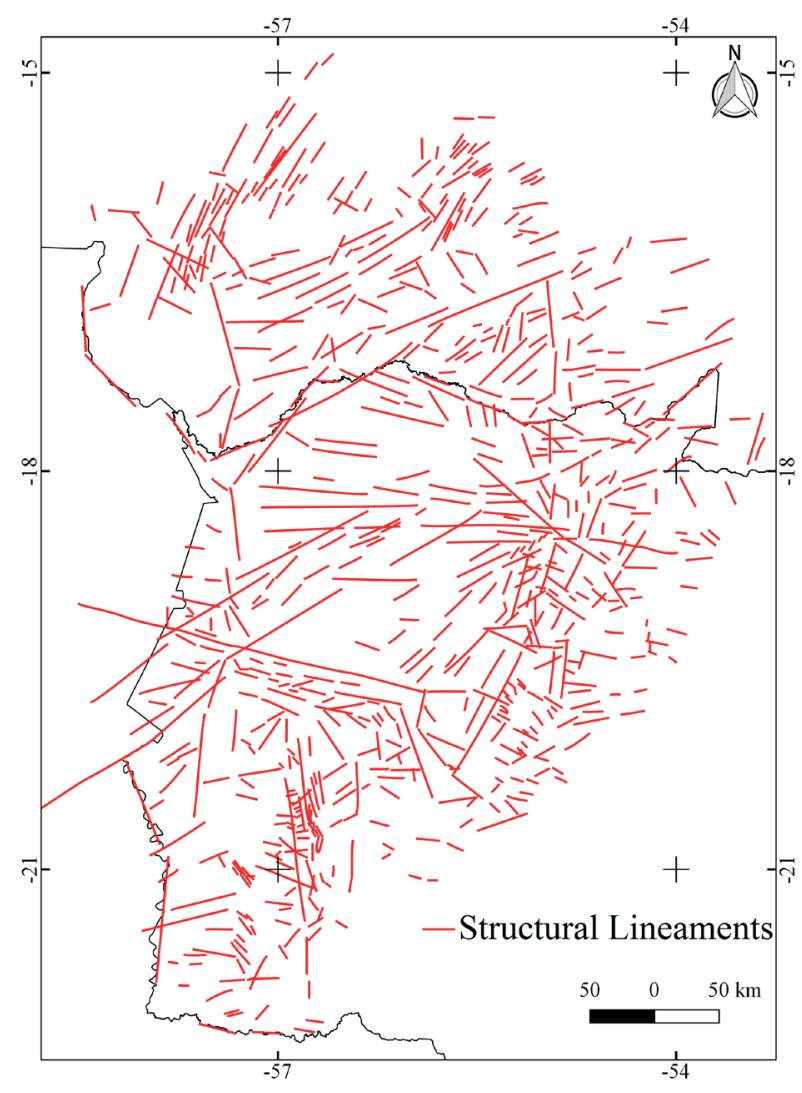

Figure 4 - Structural lineaments proposed by Paranhos Filho et al. (2013), obtained from satellite CBERS-2B, sensor MODIS images.

\section{RESULTS AND DISCUSSION}

When comparing the Pantanais boundaries with the structural lineaments, compatibility was observed among them, which suggest an important influence of these structures in the development and delimitation of these regions. Such structures act as conditioning or delimiting agents of the major rivers that, in turn, have been used as boundaries among sub-regions.

A good correlation was obtained from the first overlapping of boundaries from Adámoli (1982) and structures of Paranhos Filho et al. (2013). Only the Brazilian portion was considered, which restricted the external boundaries on the western part of Pantanal to the rivers that are used as frontiers between Brazil, Bolivia and Paraguay (Fig. 5). The coinciding external boundaries were the Cáceres River (Pantanal de Cáceres) with the Paraguay River to the south (Pantanal do Nabileque) and to the east (Serra de Maracaju). This coincidence is more evident in the sub-regions that are under the control of lineaments, such as Pantanais do Paiaguás, Nhecolândia, Aquidauana and Abobral. In association with this fact, the major rivers are used to delimit the Pantanal sub-regions.

It is observed that the delimitation proposed by Silva and Abdon (1998) also presents a strong coincidence with the lineaments proposed by Paranhos Filho et al. (2013) (Fig. 6). As Adámoli (1982), these authors took into consideration the Brazilian Pantanal only. The main difference between these delimitations is related to the Pantanal southern portion, because Silva and Abdon (1998) consider the Porto Murtinho region as Pantanal, whereas Adámoli (1982) does not. In this sense, the boundaries proposed by Silva and Abdon (1998) show structural coincidences similar to the previous boundary mainly when it comes to internal boundaries.

In the eastern portion, the boundaries mostly coincide with structural lineaments, thanks to the Maracajú Ridge. In the western portion the coincidences between Pantanais de Cáceres and Porto Murtinho result from the use of major rivers as boundaries.

In relation to the internal delimitation, a larger quantity of regions almost entirely coincident with structural lineaments is observed and also the use of rivers as boundaries between Pantanal subregions. Out of the 11 sub-regions, six present such condition: Cáceres, Barão de Melgaço, Paiaguás, Nhecolândia, Aquidauana and Abobral.

Mioto et al. (2012) proposed 18 different sub-regions for Pantanal, comprising the portions in Bolivia and Paraguay, thus differing from the other authors' external and internal boundaries. The authors also present coincidences between boundaries and lineaments (Fig. 7). 


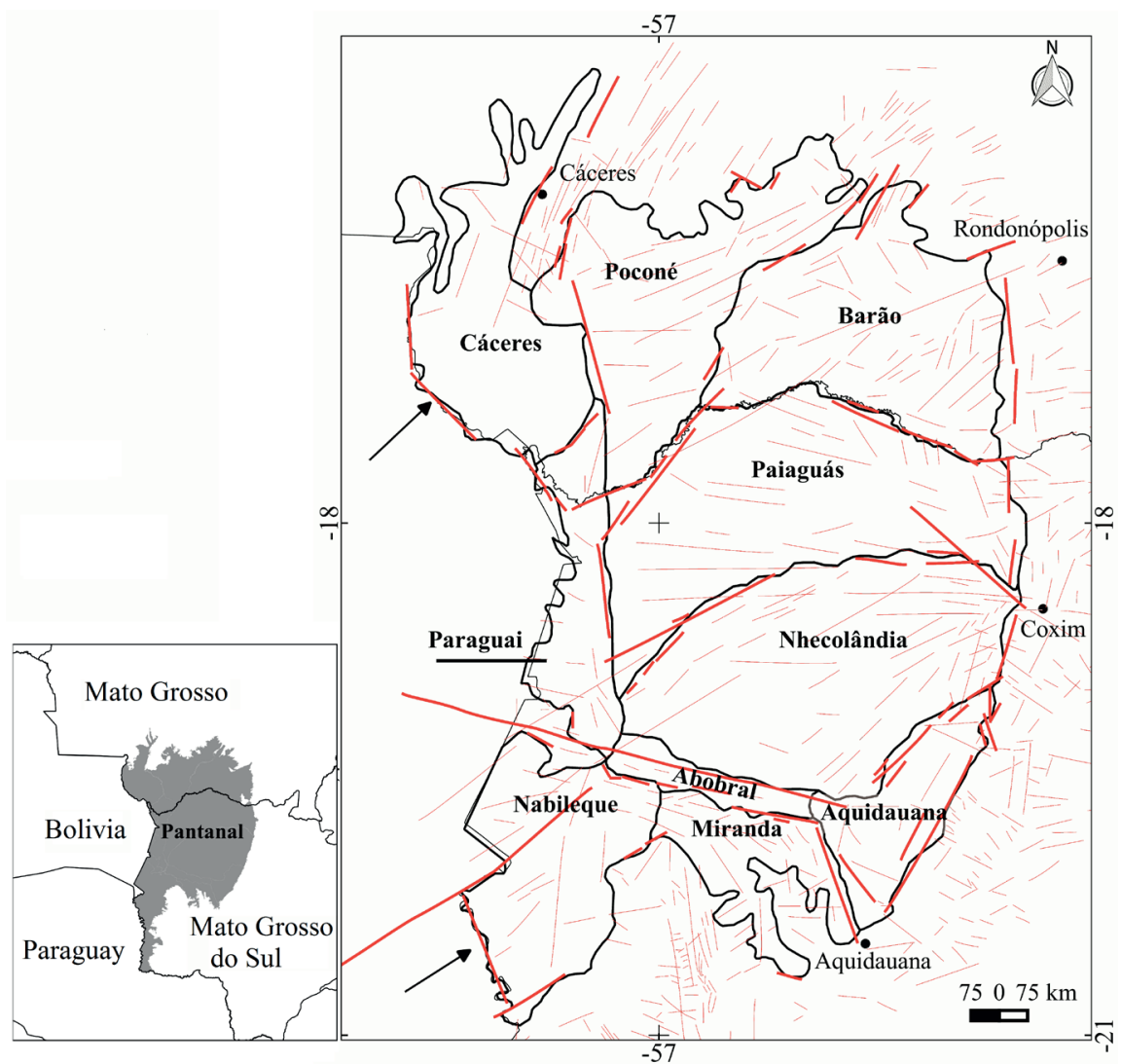

Figure 5 - Structural lineaments (in red) that coincide with the limits proposed by Adámoli (1982) (in black). The arrows to the left indicate places where the external boundaries formed by the Paraguay and Cáceres rivers coincide with the lineaments. The Adámoli sub-regions, the Pantanal, Paiaguás, Nhecolândia, Aquidauana and Abobral boundaries are almost entirely concordant with the lineaments.

In general, the coincidences are higher regarding the internal boundaries. In the eastern portion coincidences exist thanks to the Maracajú Ridge to the west, in the Pantanais do Nabileque and Apa-Amonguijá-Aquidabã, whose boundary is the Paraguay River. In the northern region, the boundary and the lineaments coincide in only a small part of Pantanal de Cáceres, related to the Paraguay-Araguaia Belt (Morraria do Mato Grosso). There is no consonance with the Cáceres River, once such authors (Mioto et al. 2012) entered the Pantanal Bolivian part.

In relation to the internal boundaries, out of the 18 sub-regions, seven present boundaries that totally coincide with the structural lineaments, which are: Pantanais do Baixo Barão de Melgaço,
Entorno Pantaneiro, Paiaguás, Taquari, Negro, Nhecolândia and Taboco.

\section{CONCLUSIONS}

From the results presented here, we conclude that there is a certain relationship between structural lineaments and the external boundaries of the Pantanal sub-regions, even when observing the limits obtained by different researchers by means of distinct datasets.

These directions are concentrated around NE-SW, $\sim \mathrm{N}-\mathrm{S}$ and $\sim \mathrm{E}-\mathrm{W}$. The two first ones are coincident with the orientation of the lineaments present in the basement of the Pantanal, and probably correspond to the reactivation of 


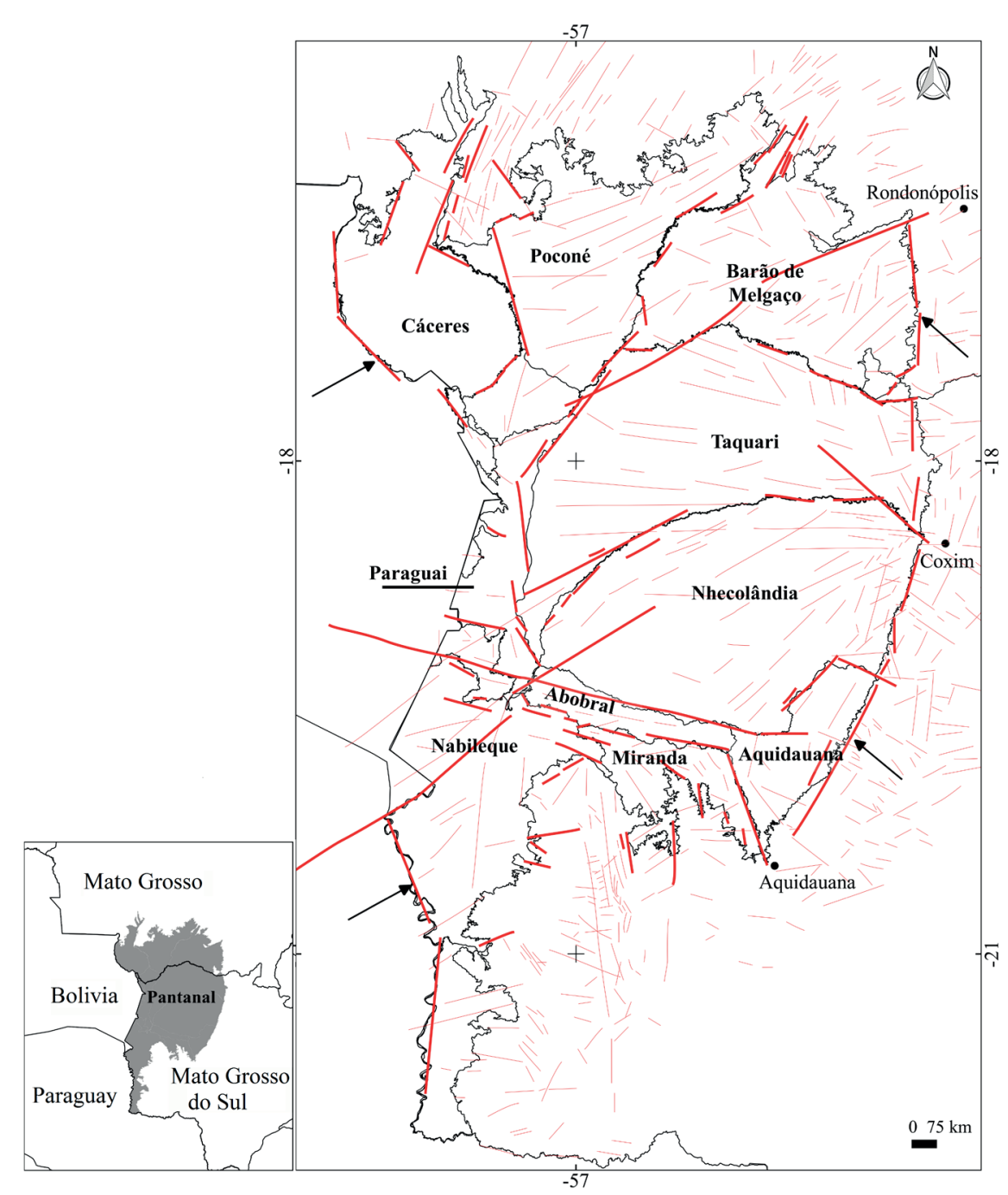

Figure 6 - Structural lineaments (in red) that coincide with the boundaries proposed by Silva and Abdon (1998) (in black). The arrows to the right indicate concordance between the lineaments and the Pantanal eastern border, characterized by the Maracajú Ridge. The arrows to the left indicate lineaments coinciding with the Paraguay and Cáceres rivers, which are used as division lines between Brazil, Paraguay and Bolivia.

structures of this basement, whereas the latter are newer structures and have been related to the E-W stress field produced in the South American Plate during the late Pleistocene to Quaternary (Paranhos Filho et al. 2013, Riccomini and Assumpção 1999).

We point out that the major coincidences occur between the Pantanal subdivisions, once the authors (Adámoli 1982, Silva and Abdon 1998, Mioto et al. 2012) use the large rivers as limits or boundaries between one region and another.
Therefore, the data obtained herein shows an excellent fit of the directions of the contacts of the sub-regions proposed in this work with the directions defined from the satellite images, combined with field data.

Finally, the main contribution of this work agrees with several studies that have discussed the evidences (geomorphological, structural, seismicity etc.) of neotectonic activity in the region, conditioning the boundaries of the simple Pantanal sub-regions. 


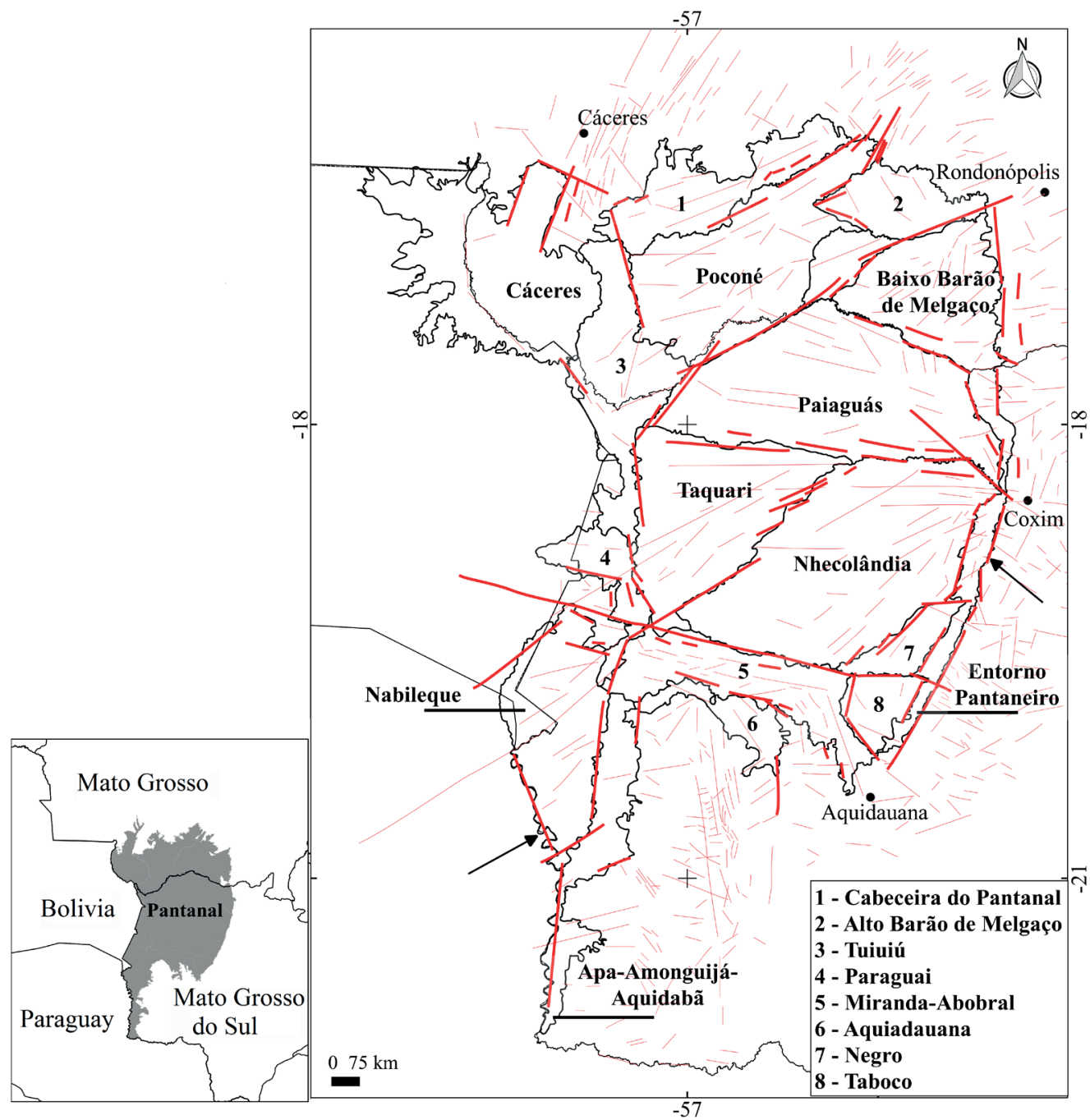

Figure 7 - Structural lineaments (in red) that coincide with the boundaries proposed by Mioto et al. (2012) (in black). The arrows indicate the external boundaries concordant with the structural lineaments, being the eastern boundary marked by the Maracajú System. The Paiaguás, Taquari, Negro and Nhecolândia (which form the Taquari River mega-fan) coincide entirely with the structures, as well as Pantanais do Taboco, Baixo Barão de Melgaço and Entorno Pantaneiro.

\section{ACKNOWLEDGMENTS}

The authors thank the Coordenação de Aperfeiçoamento de Pessoal de Nível Superior (CAPES) for the Doctorate scholarship of C. L. Mioto and Conselho Nacional de Desenvolvimento Científico e Tecnológico(CNPq) for the Productivity Research Grant (Processes 304122 / 2015-7 and 300423/82-9) of A.C. and R.M., respectively. The Fundação de Apoio ao Desenvolvimento do Ensino, Ciência e Tecnologia do Estado de Mato Grosso do Sul (FUNDECT), for granting the Regional Scientific Development scholarship, granted to Gustavo Marques Amorim (T.O.140 / 2014).

\section{AUTHOR CONTRIBUTIONS}

Camila Leonardo Mioto is a $\mathrm{PhD}$ in Environmental Technologies and contributed with the characterization of the Pantanal Matogrossense Sub-Regions, with Geoprocessing Analysis and Remote Sensing applications. Antonio Conceição 
Paranhos Filho is a PhD in Environmental Geology and contributed with his knowledge about the Pantanal, Environmental Geology, Geosciences, Geoprocessing and Remote Sensing. Gustavo Marques Amorim is a $\mathrm{PhD}$ in Geosciences, contributing with his knowledge in Geosciences and Regional Geology. Fabrício Bau Dalmas is a $\mathrm{PhD}$ in Geosciences, contributing with his knowledge in Geosciences, Remote Sensing and Hydrogeology. Antonio Roberto Saad is a PhD in Regional Geology and contributed with his knowledge about the Pantanal, basin and environmental geology analysis and water quality in watersheds. Marco Antonio Diodato is a $\mathrm{PhD}$ in biological Sciences and contributed with his experience in the area of Forest Resources and Environmental Sciences. Ana Paula Garcia Oliveira is a $\mathrm{PhD}$ in Environmental Technologies and contributed with her knowledge about the Pantanal, Geoprocessing Analysis and Remote Sensing. Romulo Machado is a PhD in General Geology and Application and contributed with his experience in the area of Ductile and Brittle Tectonics and his knowledge about the Pantanal.

\section{REFERENCES}

AB'SABER AN. 1988. O Pantanal Mato-Grossense e a teoria dos refúgios. Rev Bras Geog 50(2): 9-57.

AB'SABER AN. 2006. Brasil, paisagens de exceção. O litoral e o Pantanal Mato-Grossense. Patrimônios Básicos. São Paulo: Ateliê Editorial, 182 p.

ADÁMOLI J. 1982. O Pantanal e suas relações fitogeográficas com os Cerrados. Discussão sobre o conceito de "Complexo do Pantanal". In: Congresso Nacional da Sociedade Botânica, 32, Teresina, Piauí.

ALMEIDA BS, MACHADO R, MIOTO CL, OLIVEIRA JRS, MARCATO JUNIOR J, SAAD AR, FACINCANI EM AND PARANHOS FILHO AC. 2015. Geotecnologias e sismos no Pantanal. In: Simpósio Nacional de Estudos Tectônicos, 15 - International Symposium on Tectonics, 9. Vitória, ES, p. 404-407.

ALMEIDA FMM. 1945. Geologia do sudoeste MatoGrossense, Brasil. Divisão de Geologia e Mineralogia, Rio de Janeiro: DNPM 116: 9-115.

ALMEIDA FFM. 1965. Geologia da Serra da Bodoquena (Mato Grosso). Divisão de Geologia e Mineralogia, Rio de Janeiro: DNPM 219: 1-96.
ALMEIDA FMM. 1967. Origem e evolução da plataforma brasileira. Divisão de Geologia e Mineralogia, Rio de Janeiro: DNPM 241: 1-36.

ANDRADES FILHO CO AND FONSECA LMG. 2009. Lineamentos estruturais a partir de imagem Landsat TM e dados SRTM. In: Simpósio Brasileiro de Sensoriamento Remoto, 14. Natal, RN, p. 3151-3158.

ASSINE ML. 2010. Pantanal Mato-Grossense: uma paisagem de exceção. In: Modenesi-Gauttieri MC, Bartorelli A, Mantesso-Neto V, Carneiro CDR and Lisboa MBAL (Eds), A Obra de Aziz Nacib Ab'Saber. São Paulo: Beca, p. 464-489.

ASSINE ML, MERINO ER, PUPIM FN, WARREN LV, GUERREIRO RL AND MCGLUE MM. 2016. Geology and Geomorphology of the Pantanal Basin. In: Bergier I and Assine ML (Eds), Dynamics of the Pantanal Wetland in South America. The Handbook of Environmental Chemistry 37, Springer Cham, p. 23-50.

ASSINE ML AND SOARES PC. 2004. Quaternary of the Pantanal, west-central Brazil. Quaternary Int 114(1): 23-34.

ASSUMPÇÃO M. 1998. Focal mechanisms of small earthquakes in the southeastern Brazilian shield: a test of stress models of the South American plate. Geophys J Intern 133(2): 490-498.

ASSUMPÇÃO M, BIANCHI M, JULIÀ J, DIAS FL, FRANÇA GS, NASCIMENTO R, DROUET S, PAVÃO CG, ALBUQUERQUE DF AND LOPES AEV. $2013 \mathrm{a}$. Crustal thickness map of Brazil: Data compilation and main features. J South Am Earth Sci 43: 74-85.

ASSUMPÇÃO M, FENG M, TASSARA A AND JULIÀ J. 2013b. Models of crustal thickness for South America from seismic refraction, receiver functions and surface wave tomography. map of Brazil: Data compilation and main features. Tectonophysics 609: 82-96.

ASSUMPÇÃO M, FERNANDES CM AND FACINCANI EM. 2009b. O sismo do Pantanal de 15/06/2009 de magnitude 4,8. In: Congresso Brasileiro de Geofísica, 11. Salvador, Bahia.

ASSUMPÇÃO M, LOPER AEV, ZEVALLOS I, FERREIRA JM AND NASCIMENTO A. 2009a. Intraplate Stress Field in Brazil from Earthquake Focal Mechanisms. In: Conferencia Internacional en Homenaje a Alberto Giesecke. Lima, Peru.

ASSUMPÇÃO MAND SUÁREZ G. 1988. Source mechanisms of moderate-size earthquakes and stress orientation in midplate South America. Geophysl J Int 92(2): 253-267.

BRANNER JC. 1912. Earthquakes in Brazil. Bull Seismic Soc Am 2(2): 105-117.

ECKEL EB, MILTON C AND SULSONA PT. 1959. Geology and mineral resources of Paraguay -a reconnaissance, with sections on Igneous and metamorphic rocks and soils. Geological Survey Professional Paper: 327. 
FACINCANI EM, ASSUMPÇÃO MS, ASSINE ML AND FRANÇA GLS. 2011. Sismicidade da Bacia do Pantanal Mato-Grossense. In: Simpósio Nacional de Estudos Tectônicos (SNET), 13. Campinas, São Paulo, p. 314-317.

FREITAS RODE. 1951. Ensaio sobre a tectônica moderna do Brasil. Boletim da Faculdade de Filosofia Ciências e Letras, Universidade de São Paulo. Geologia 6: 7-107.

HASUI Y. 1990. Neotectônica aspectos fundamentais da tectônica ressurgente no Brasil. In: Workshop sobre a Tectônica e Sedimentação Cenozóica Continental no Sudeste Brasileiro. Belo Horizonte, p. 1-31.

HASUI Y. 2010. A grande colisão pré-cambriana do sudeste brasileiro e a estruturação regional. Geociências 29: 141169.

HORTON BK AND DECELLES PG. 1997. The modern foreland basin system adjacent to the Central Andes. Geology 25(10): 895-898.

KUERTEN S AND ASSINE ML. 2011. O rio Paraguai no megaleque do Nabileque, sudoeste do Pantanal MatoGrossense, MS. Rev Bras Geoc 41(4): 642-653.

MIOTO CL, ALBREZ EA AND PARANHOS FILHO AC. 2012. Contribuição à caracterização das sub-regiões do Pantanal. Rev Entre-Lugar 3(6): 165-180.

O'LEARY DW, FRIEDMAN JD AND POHN HA. 1976. Lineament, linear, lineation: some proposed new standards for old terms. Geol Soc Am Bull 87(10): 1463-1469.

PARANHOS FILHO AC, MIOTO CL, MACHADO R, GONÇALVES FV, RIBEIRO VDEO, GRIGIO AM AND SILVA NMDA. 2017. Controle Estrutural da Hidrografia do Pantanal, Brasil. Anua Inst Geoc 40(1): 156-170.

PARANHOS FILHO AC, NUMMER AR, ALBREZ EDOA, RIBEIRO AA AND MACHADO R. 2013. A study of structural lineaments in Pantanal (Brazil) using remote sensing data. An Acad Bras Cienc 85: 913-922.

PUTZER H. 1962. Die geologie von Paraguay. Beitr Reg Geol Erde 2: 1-182.

QGIS DEVELOPMENT TEAM. 2015. QGIS Geographic Information System. Version 2.12. Lyon.

RICCOMINI C AND ASSUMPÇÃO M. 1999. Quaternary tectonics in Brazil. Episodes 22(3): 221-225.

SILVA JSV. 1995. Elementos fisiográficos para delimitação do ecossistema Pantanal: Discussão e Proposta. Oecologia Brasiliensis, Estrutura, Funcionamento e Manejo de Ecossistemas Brasileiros. PPGEUFRJ, Rio de Janeiro, p. 439-458.

SILVA JSV AND ABDON MM. 1998. Delimitação do Pantanal Brasileiro e suas sub-regiões. Pesq Agrop Bras 33(3): 1703-1711.

SOARES PC, ASSINE ML AND RABELO L. 1998. The Pantanal Basin: Recent Tectonics, Relationships to the Transbrasiliano Lineament. In: Simpósio Brasileiro de Sensoriamento Remoto, 11, Santos, p. 459-469.

USP - IAG. 2016. Institute of Astronomy, Geophysics and Atmospheric Sciences of the University of São Paulo. http://www.iag.usp.br/international/.

USP - U.D.S.P. 2014. Boletim Sísmíco Brasileiro - Centro de Sismologia. Boletim Sísmíco Brasileiro, 2014. Disponível em: < http://www.moho.iag.usp.br/rq/ >.

USSAMI N, SHIRAIWA SS AND DOMINGUEZ JML. 1999. Basement reactivation in a sub-Andean foreland flexural bulge: The Pantanal wetland, SW Brazil. Tectonics 18(1): 25-39.

ZANI H AND ASSINE ML. 2011. Paleocanais no megaleque do rio Taquari: mapeamento e significado geomorfológico. Rev Bras Geoc 41(1): 37-43. 